\title{
THE INFLUENCE OF THE TRADITIONAL MARKET IMAGE ON THE SUCCESS OF SOLO CITY BRANDING
}

\author{
S P Putri ${ }^{1}$
}

Received: 14 September 2019

Accepted: 29 November 2019

\begin{abstract}
The positive image of the city plays a strong role in determining the success of city branding. The positive image of the city makes it easier to form competitive advantages. These city images can be communicated in various ways, and one of them through culture. This research was conducted to determine the influence of the image of traditional markets as a part of the culture of Solo in attracting residents and tourists to stay and visit. Multiple linear regression is used to test and find traditional market image factors that influence the success of city branding. The study used 120 samples consisting of residents and tourists. Sampling uses the combined sampling method. The results of the study show that there is an influence between the traditional market image on the success of city branding. Traditional markets have been proven to be able to influence the formation of a positive image of Solo although it is not the only determinant of the success of city branding. Traditional market condition and traditional market reputation are significant factors in attracting residents and tourists to stay and visit Solo.
\end{abstract}

Keywords: traditional market, city branding, city image

\section{INTRODUCTION}

City branding is a strategy of a city to achieve competitive advantage . City branding can increase the competitiveness of a city. This competitiveness can be used by a city to compete in the global era. On the other side, a strong positive image of the city can make the formation of such competitive advantages easily (Rainisto, 2003) This image can be communicated through three strategies: primary (physical aspects), secondary (advertising), and tertiary. In the case of cities in the world, culture as part of the primary communication of city image has a major role in supporting city branding (Bıçakçı, 2012). That way, they are interrelated.

There are many studies that show the role of the city culture on city branding. Cultural activities, iconic architecture, mega-events, cultural villages and museums become culture representations as controversial tools in city branding (Bıçakçı,2012; Riza, 2015; Dragolea and Cotirlea, 2012; Fan, 2013). This research contributes to enriching the role of culture through different forms in city branding. The results of this study also contribute to a new perspective on the branding of media used in developing countries. Traditional markets in Indonesia are a reflection of the culture inherent in the identity of cities in Java. This phenomenon may be different in the context of developed countries.

Solo is one of the cities that uses culture as its identity. The city's culture is used to attract residents and visitors. Some cultural embodiments include the Surakarta Palace, ritual traditions, gamelan, batik, javanese language, keroncong music, traditional dance, traditional building pattern, and the character of a friendly and polite Javanese people. Traditional

\footnotetext{
${ }^{1}$ Urban and Regional Planning Master Program, School of Architecture, Planning, and Policy Development, Bandung Institute of Technology
}

Korespondensi: shintapermanaputri@gmail.com 
markets can also be seen as a cultural asset of a city. The existence of traditional market is a condition for the existence of a palace in Java. According to Catur Gatra Utama, traditional markets are a symbol of livelihood.

Culture as one of the primary communication media should be able to strengthen the positive image of the city and encourage the success of city branding. However, in reality traditional markets as a manifestation of culture cannot always form a strong positive image in each city. The existence of a traditional market as an example or an icon of a city is not always able to attract residents to stay or attract tourists to visit a city. Therefore, this research is still needed regarding the influence of traditional market images on the success of Solo's city branding.

\section{City Image}

City image can be interpreted as a number of knowledge, feelings, thoughts, experiences and unique impressions of a person towards a city that is built through a variety of long activity processes (Rainisto, 2003; Yananda \& Salamah, 2014). This city image is intended as a response for intercity competition in the era of globalization (Braun, Eshuis, and Klijn, 2014)

Rainisto (2003) and Avraham and Ketter (2008) explain that if one city has a strong positive image and combined with good city marketing efforts, the city can easily form competitive advantages (Rainisto, 2003; Avraham and Ketter, 2008; Anholt, 2007). This competitive advantage will contribute to improve city competitiveness (Avraham and Ketter, 2008).

The image of a city can be communicated through various forms such as the physical environment, events organizing such as music, art, and sports and through well-known figures from the city (Dinnie, 2011; Kavaratzis, 2004; Lynch, 1960). In addition, cultural aspects in the form of facilities, events organizing, architecture and urban history also play an important role in the formation and strengthening of the city's image (Bıçakçı, 2012)

Kavaratzis (2004) and Braun, Eshuis and Klijn (2014) summarize this into three city image communication options consisting of primary, secondary, and tertiary communication.

The image of a city will be created if the concept of identity inherent in the city is clear (Rainisto, 2003). This image is formed through four components (Gartner, 1993). They are cognitive (what someone knows about place), affective (how someone feels about a certain place), evaluative (how someone evaluates the plave or its residents), and behavioral (whether it is considered to be working to/visiting/investing in a certain place)

\section{City Branding}

City branding is one of the strategies in achieving competitive advantage to market the city (Kavaratzis, 2004). Branding is believed to be the best way of influencing perceptions and imagery about a city (Kavaratzis, 2005; Ashworth and Kavaratzis, 2010). Its main objective is to increase the attractiveness of a city, achieve competitive advantages regionally and internationally, and enhance corporate reputation that improves its economical importance (Rainisto, 2003; Rehan, 2014). The success of city branding is determined by its ability to attract residents and visitors (Moilanen and Rainisto, 2009). Their pleasure and satisfaction are the main goals in an effort to market the city through city branding (Dinnie, 2011; Kavaratzis 2004; Yananda \& Salamah, 2014). The success is determined by the perceptions of visitors and tourists. The success can also be measured using the Hexagon City Brand Index which consists of:

a. The Presence, emphasizes the status and position of a city to international level 
b. The Potential, emphasizes the ability of a city to shape the perception of pleasure and attraction of a person towards the physical aspects of a city

c. The People, emphasizes the ability of a city to provide economic and educational opportunities to visitors, business people and migrants.

d. The Prerequisites, emphasizes the ability of a city to create a vibrant lifestyle for people who live in it

e. The Pulse, emphasizes the friendliness and openness of citizens, city security, and the ability of a city to create a community conducive to language and cultural exchange

f. The Place, emphasizes the ability of cities to provide basic services related to their level of satisfaction (Anholt, 2007)

\section{METHODS}

This section will explain the unit of observation and analysis of this study, sampling frame, and data analysis methods

\section{Unit of Observation an Analysis}

The unit of observation in this research is focused on 3 sub-districts in Solo, namely Banjarsari, Pasar Kliwon, and Jebres. The three traditional markets in Solo, namely Pasar Gedhe, Pasar Klewer and Pasar Triwindu were chosen as specific observation units in seeing the influence of traditional market images in supporting the success of Solo City branding. These three traditional markets become observation units because they have their own unique traditional market criteria. This uniqueness is seen from the value of its history, product distinctiveness, and also the classification of visitors. This uniqueness is considered as the image of traditional market in Solo.

The unit of analysis includes variables and indicators that have been determined through the deduction of theory. The study variables are described in Table 1.

\section{Population and Sampling Method}

The population in this study is the three sub-subdistricts of Solo, with a total number of 60,238 people. This population is determined through several stages. First, the determination of the population is done by selecting sub-districts in Solo which are considered to have a unique traditional market. Second, selecting sub-subdistricts from previously selected sub-districts. The criteria used are sub-subdistrict that have the highest number of traditional markets in selected sub-districts. In addition, the population also comes from tourists or visitors in Solo, which amounts to 371,000 visitors. This number is determined through direct calculations in the field. The number of samples used in this study were 120 samples with a confidence level of $90 \%$. The sampling method used is combined sampling. Combined sampling is applied differently between residents and tourists. For population samples, proportional multistage sampling is used. For tourist, proportional accidental sampling is used

\section{Data Analysis Method}

The results of the data collection were analyzed using inferential statistical methods with the help of SPSS software. The inferential technique used is multiple linear regression. This statistic is used to test the influence of traditional market image on the success of Solo's city branding and find out the factors that influence it. Before performing statistical testing, the first step is to give a score/variable code. Factor analysis is also used to minimize correlations between existing variables and also summarize existing variables. Several 
assumption tests were also conducted to determine the feasibility of using multiple linear regression. Furthermore, descriptive statistics are carried out to provide supporting meaning. These statistical results can be used as supporting analysis in interpreting the results of previous statistical processing.

Table 1.Variables of City Image dan City Branding

\begin{tabular}{|c|c|}
\hline Variables & Indicators \\
\hline \multicolumn{2}{|c|}{ Traditional Market } \\
\hline $\begin{array}{l}\text { - Knowledge of traditional markets Market } \\
\text { popularity } \\
\text { - Understanding of traditional market Physically } \\
\text { condition of traditional market Traditional market } \\
\text { services } \\
\text { - Visiting Experience Product completeness } \\
\text { Commodity prices Market situation } \\
\text { - Interest in visiting }\end{array}$ & $\begin{array}{l}\text { - Level of knowledge about traditional market } \\
\text { Perception of market popularity } \\
\text { - Level of understanding of the traditional market } \\
\text { Perception of traditional market physical } \\
\text { conditions Perception of traditional market service } \\
\text { - Visit intensity level Perceived product } \\
\text { completeness } \\
\text { - Perception of market commodity prices } \\
\text { - Perception of the market situation } \\
\text { - Level of visiting consideration }\end{array}$ \\
\hline
\end{tabular}

City Branding

- Familiarity with the city Knowledge of the city Visiting experience City popularity

- Pleasure for the physical aspects of the city Interest in the physical aspects of the city Economic opportunities

- Job opportunities Educational opportunities

- Conformity becomes a place of business Tourist opportunities

- The opportunity to hold an interesting event

- The ease of finding interesting things A vibrant lifegenerating ability Ability to create additional experiences Friendliness and openness of citizens City security

- Opportunities for creating a conducive community for knowledge sharing

- Satisfaction with city services Ability to accommodate needs
- Level of familiarity with the city Level of knowledge about the city

- The level of desire to stay longer in the city The level of popularity of the city

- The level of pleasure in the city Level of interest in the city

- Perception of economic opportunities given by the city Perception of job opportunities offered by the city

- Perception of opportunities for education provided by the city The level of compatibility as a place of business

- Perception as tourist place opportunities given by the city

- Match level as the venue for the event

- The level of ease of finding interesting experiences in the city A vibrant level of life-generating ability

- The level of ability adds to the experience

- The level of friendliness and openness of the population Perception as a safe place

- The level of ability creates kinship relations

- Level of satisfaction with city services Perception as a place that provides complete living facilities

\section{RESULT AND DISCUSSION} follow:

Based on the results of data processing using statistical methods, the results are as

\section{The Influence of traditional market image on the success of Solo's city branding}

The factor analysis test was conducted first before multiple linear regression tests. This test is conducted to form the image factor of a new traditional market based on a number of constituent variables. Traditional market image variables that correlate strongly with other traditional market image variables tend to cluster into new factors forming traditional market images. Based on the results of factor analysis, there are three new factors related to the image of traditional markets. The composition of these three factors is shown in Table 2. 
Table 2.The Composition of Traditional Image Factors (New)

\begin{tabular}{|c|c|c|c|c|c|}
\hline & \multicolumn{3}{|c|}{ Component } & \multirow{2}{*}{$\begin{array}{c}\text { Traditional Market Image } \\
\text { Factors (New) }\end{array}$} & \multirow{2}{*}{$\begin{array}{l}\text { Variables of Traditional Market } \\
\text { Image Compiler }\end{array}$} \\
\hline & 1 & 2 & 3 & & \\
\hline$\overline{\mathrm{CT} 9}$ & ,873 &, 125 & ,073 & Market Conditions (KP) & Physical condition of the market \\
\hline CT10 & 852 & 098 & 124 & & (CT4), market situation (CT9, visiting \\
\hline CT4 &, 729 &, 173 &, 164 & & interest \\
\hline CT6 &,- 079 & ,780 &,- 155 & & (CT10) \\
\hline CT1 & ,093 & ,707 & ,304 & Market Reputation (RP) & Knowledge of market (CT1), market \\
\hline CT2 & ,384 & 652 & 176 & & popularity (CT2), understanding of \\
\hline CT7 & ,115 & 612 & ,344 & & markets (CT3), visiting experience \\
\hline СТ3 & ,296 &, 538 & 626 & & (CT6), product completeness (CT7) \\
\hline CT5 & 229 &,- 071 & ,737 & Market Services (PP) & Market services (CT5), product \\
\hline CT8 &, 025 & 129 &, 718 & & prices (CT8) \\
\hline
\end{tabular}

These three traditional market image factors formed serve as the input in multiple linear regression analysis. These three new factors become independent variables that do not have any correlation with each other. In this study, regression analysis was carried out in two processes. In the first regression process, one of the insignificant traditional market image factors was found.

Based on the two regression models formed, the best model selection was chosen. The purpose of this selection is to get the best interpretation of the correlation pattern that is formed between the traditional market image and the success of city branding. The second regression model is chosen as the final model. This model is deemed worthy of being a predictor because it has fulfilled the requirements of the classic assumption test and also the feasibility test of the model. This model produces the output shown in Table 3.

Table 3.The Coefficient of Determination (R2)

\begin{tabular}{llllll}
\hline Model & $\mathrm{R}$ & $\mathrm{R}$ Square & $\begin{array}{l}\text { Adjusted R } \\
\text { Square }\end{array}$ & $\begin{array}{l}\text { Std.Error of } \\
\text { the Estimate }\end{array}$ & $\begin{array}{l}\text { Durbin } \\
\text { Watson }\end{array}$ \\
\hline 1 &, 613 &, 376 &, 359 & 5,53096 & 1,800 \\
\hline
\end{tabular}

The number 0.371 in the coefficient of determination $\left(\mathrm{R}^{2}\right)$ means that $37.1 \%$ of the variation in the variables of city branding can be explained by traditional market image variables. The low coefficient of determination ( $R$ Square) indicates that the traditional market image variable has not been able to fully influence the success of city branding in a city. In this case, the traditional market is not the only determinant of the success of city branding.

The reputation attributes and perceived attributes of the traditional market have not been able to attract residents and tourists to stay in and visit Solo optimally. This is normal because traditional markets are only a small part of the image of a city. Traditional markets are only one of the physical aspects of a city that can be used as a primary communication for a city.

Other preferences towards Solo as a place of residence and tourist destination explains the small role of traditional market image in supporting the success of city branding. For the resident, the emotional ties with Solo as a hometown, the existence of family ties in Solo, and the comfortable environment are the main drivers of people's preferences in choosing to live in Solo. For tourists, the main drivers of their preference for visiting Solo are the proximity of the location, low prices, complete facilities, and the diversity of organizing the festival.

Based on the chosen model it can also be said that the traditional market reputation factor (RP) has a greater role in supporting the success of city branding in Solo as shown in 
Table 4. This can occur because the traditional market reputation attribute (RP) becomes the first one that create one's expectations about a place through the cognitive processes. The magnitude of the influence of market reputation factors is evidenced by the number of visitors who come to Solo only because they know the market is famous.

Table 4.Multiple Linear Regression

\begin{tabular}{|c|c|c|c|c|c|c|}
\hline \multirow[t]{2}{*}{ Model } & \multicolumn{2}{|c|}{$\begin{array}{l}\text { Unstandardized } \\
\text { Coefficients }\end{array}$} & \multirow[b]{2}{*}{ Beta } & \multirow[t]{2}{*}{$\begin{array}{l}\text { Standardized } \\
\text { Coefficients }\end{array}$} & \multirow[t]{2}{*}{$\mathrm{t}$} & \multirow[t]{2}{*}{ Sig. } \\
\hline & B & Std.Error & & & & \\
\hline$\overline{\text { (Constant) }}$ & 67,608 & 504 & & & 134,036 & ,000 \\
\hline Market Condition (KP) for analysis 1 & 2,885 &, 507 & ,418 & & 5,696 & ,000 \\
\hline Market Reputation (RP) for analysis 1 & 3,068 & ,507 & ,444 & & 6,057 &, 000 \\
\hline
\end{tabular}

Market conditions factors are only supporting factors. This factor can create a further assessment after someone knows, understands, and feels how the traditional market is imaged. In this case the traditional market is not only seen as the primary communication media. In fact, the traditional market as an embodiment of the physical infrastructure of trade can also merge into a secondary communication through the media that represents it. In addition, traditional markets are known through stories that are spread from person to person as a tertiary communication media of city image. This is possible because the image is formed by the perception of someone who is influenced by his direct experience or information that comes from outside the person (such as stories of people and the media that represents it).

The influence of traditional market image can be seen in the six dimensions of the success of city branding shown in Figure 1. In the figure, it can be seen that there are several things related to the influence of traditional market images in the six dimensions of city branding:

1. Traditional markets that offer an ethnic atmosphere have influenced respondents' positive perceptions that Solo has many interesting things and places to watch and visit so that it can add new experiences (pulse dimensions).

2. Traditional markets that reflect the activities of the people of Solo City have a positive perception that people in Solo are friendly and sociable people that create opportunities for the formation of new relations (people dimension).

3. Traditional markets that become trading facilities influence the positive perception that Solo City is able to accommodate daily needs for residents and tourists who visit it (the dimensions of prerequisites).

4. The traditional market which is one of the historical buildings influences the positive perception that the City of Solo has the physical aspects of the city that is worth visiting (place dimension).

5. Famous traditional markets in various media influence the positive perception that Solo City is a famous city (presence dimension).

6. However, traditional markets are only able to influence positive perceptions such as opportunities for education, economic opportunities, tourism opportunities, opportunities for business places, and opportunities for organizing festivals (potential dimensions). 


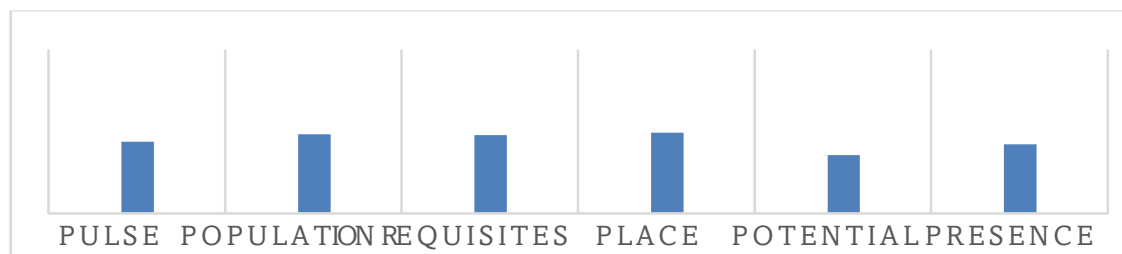

Figure 1.The Respondent's Response of Six Dimensions of City Branding

\section{Traditional Market Image that Influence The Success of Solo's City Branding}

The two significant traditional market image factors in statistical tests have different influences in determining the success of city appeal for residents and tourists. The difference in influence is caused by differences in the use of traditional markets. For residents, the market is not only a place of recreation but also to fulfill their daily needs, do social interaction, work, and also preserve culture. It is also influenced by the level of understanding of the market. According to Figure 1, 97\% of the population has a higher understanding process in creating the market reputation in their minds. This is also influenced by the intensity of visits. Eight out of ten residents in Figure 1 claimed that they often visit the market because of its close location

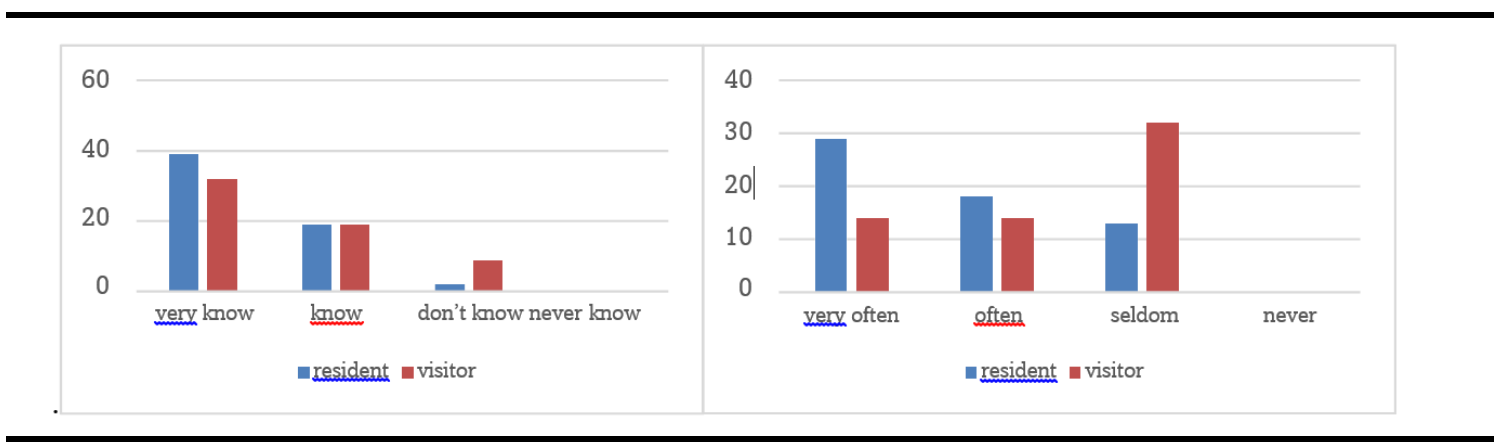

Figure 2.Level of Traditional Market Knowledge and Intensity of Visiting Traditional Market by Residents and Tourists

Tourists have a lower interest in visiting traditional markets when compared to residents. Figure 1 shows that the percentage of tourists who want to revisit the traditional markets decreases by $90 \%$. However, $90 \%$ of the tourists shown in Figure 1 say that traditional markets are still interesting to visit. This is influenced by the visual experience of tourists in creating perceptions regarding market conditions.

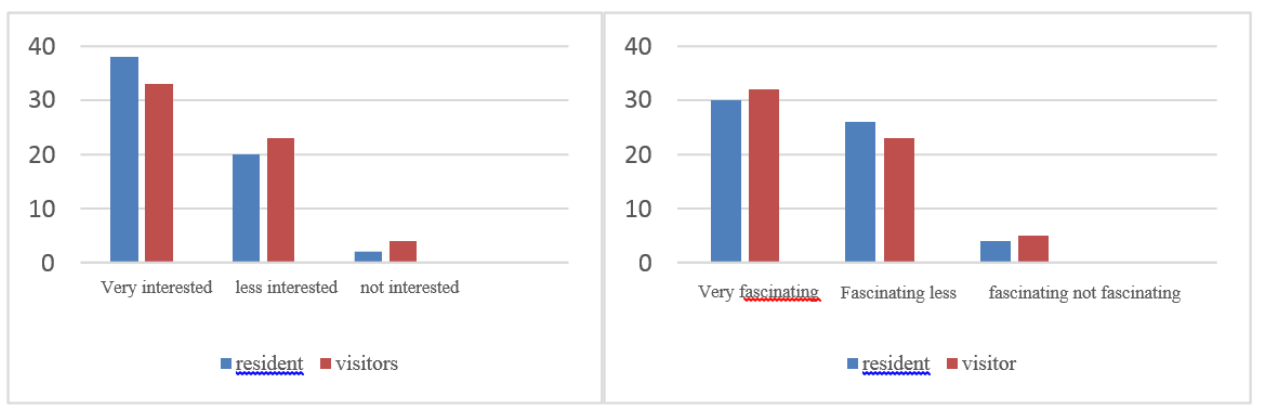

Figure 3.Level of Traditional Market Interest by Residents and Tourists 
For residents and tourists, the reputation factor is their main driving attribute for visiting. The popularity, fame, and good reputation of the traditional market will increase their curiosity to do a personal visiting experience. They decide to visit it even though they have not yet known how the market provides and realizes their expectations. The market conditions factor is certainly a supporting factor in creating the expectations of residents and tourists about traditional markets. These factors are important in creating their satisfaction and comfort in order to maintain a commitment to visit traditional markets.

Based on the percentage of knowledge of residents and tourists about traditional markets in Solo, traditional markets can be mapped on the categories of traditional markets that have succeeded in becoming city branding media and traditional markets that have the potential but have not yet been developed as less potential city branding and market media as shown in Figure 1. In this case the Pasar Gedhe, Pasar Klewer, and Pasar Triwindu are classified as very potential and have succeeded in becoming a branding because they have traditional values, commodity specificities, accessibility, service coverage, price offered, and a prominent festival. Twenty-three other traditional markets that have the potential to become branding media have commodity characteristics, accessibility, service coverage, prices offered, and the organization of festivals that can still be optimized in an effort to market the city.

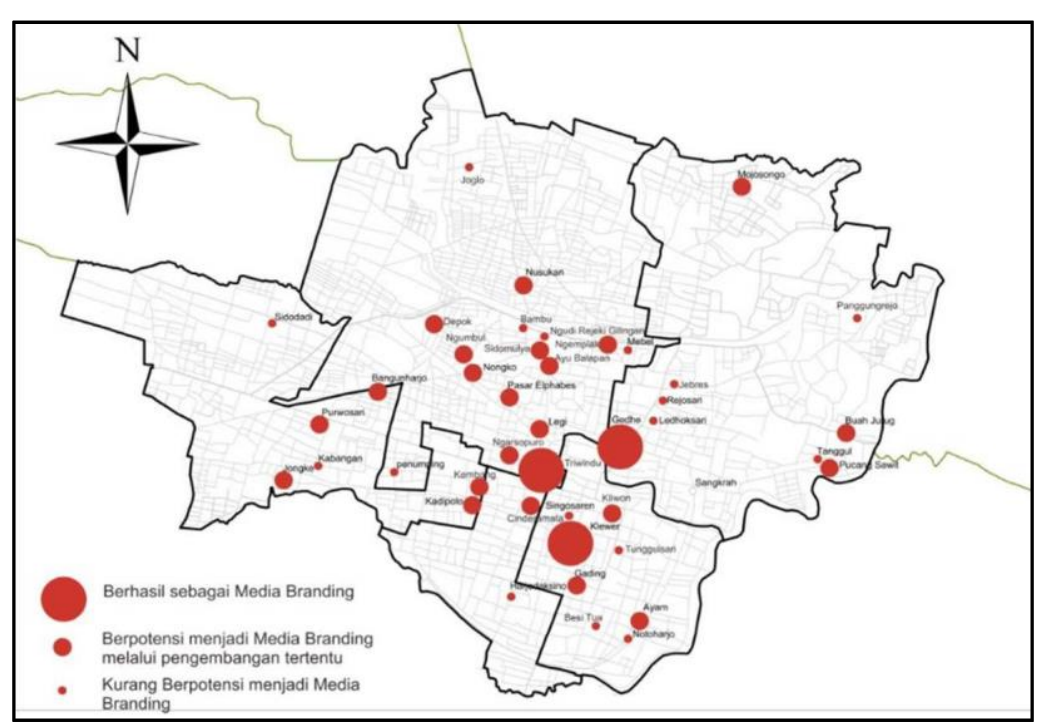

Figure 4. Classification of Traditional Markets as City Branding Media

\section{RESULT AND DISCUSSION}

In this study it can be concluded that there is an influence of traditional market image as the primary communication media of city image on the success of city branding as indicated by the determinant coefficient (R Square). This finding is in accordance and strengthen the opinion of Braun, Eshuis, and Klijn (2014) and Rainisto (2003) who found that primary communication media indeed proved to be an effective city branding strategy. However, this influence can only be explained by traditional market image variables which are shown from the value of R Square which is still relatively low. This evaluates the strategy scheme in the city branding effort developed by Rehan (2014) which states that historical buildings can become reliable media. In fact, traditional markets as the embodiment of historical buildings still need to be optimized as a branding media.

Traditional markets as a city image have not been able to fully represent the simplification of many associations and information relating to a city such as the definition 
of city image intended by Rainisto (2003). This is be in accordance with the opinion of Dinnie (2011) , OECD in (Dinnie, 2011; Bıçakçı, 2012) that city branding efforts through culture can not only be done through traditional markets. There are still many forms that can be developed in further research such as historical buildings, festivals, traditions/rituals, arts, and history of the city. These efforts must be synergized with other primary communication media (Bıçakçı, 2012) and (Kavaratzis, 2004), secondary communication and tertiary image of the city through planned advertising media and stories that are spread from person to person [9].

There are two factors that form the image of a traditional market that significantly affect the success of the city branding. Both factors are factor of market conditions and also factor of the reputation of traditional markets. These two factors have a greater influence in determining the success of city branding in the population compared to tourists. This finding is in accordance with Dinnie (2009) who stated that in order to attract residents to stay, a city must be able to support its long-term commitment by fulfilling the basic needs while tourists depend on their perception of their visual experience.

\section{REFERENCES}

Anholt S 2007 Competitive Identity: The New Brand Management for Nations, Cities and Regions (Great Britain: Palgrave Macmillan)

Ashworth G and Kavaratzis M 2010 Towards Effective Place Brand Management: Branding European Cities and Regions (Northampon: Edward Elgar PublishingInc)

Avraham E and KetterE 2008 Media Strategies for Marketing Place in Crisis: Improving the Image of Cities, Countries, and Tourist Destinations(Great Britain: ElseiverInc)

Bıçakçı AB 2012 branding the city through culture: istanbul, European capital of culture 2010

J.Hum. Sci. 9931006.

Braun E, Eshuis J and Klijn EH 2014 the effectiveness of place brand communication $J$.

Urb.Pol. and Plan.6470

Dinnie, K 2011, City branding Theory and Cases, Palgrave Macmillan, Great Britain

DragoleaLL and Cotirlea DA2012one step closer to city branding through culture: consumer preferences for cultural tourism services in alba iula-customization on national museum of unificationAnnales Universitatis Apulensis Series Oeconomica680 87

Fan H2013 place branding through its culture heritage - the working case of branding daquan village into the tofu village Proc. Int. Conf. on City Branding Symps(Beijing) p 121

Kavaratzis M 2004 from city marketing to citybranding: towards a theoritical framework for developing city brands J.Place. Brand 5873

Kavaratzis Mand Ashworth G 2005 city branding: an effective assertion of identity of a transitory marketing trick J.Eco and Soc Geo.50614

Lynch, K. (1960). The city image and its elements. MIT Press, Cambridge, 41, 73.

Rainisto SK 2003 Success Factors of Place Marketing:A Study of Place Marketing Practices in Northern Europe and The United States(Helsinki: Helsinki Universityof Technology)

Rehan RM 2014 urban branding as an effective sustainability tool in urban development $J$.

Housing and Building. 22230

Riza M2015 culture and city branding: mega-events and iconic building as fragile means to rand the city J.SocScie. 26974

Yananda MR \& SalamahU 2014 Branding Tempat: Membangun Kota, Kabupaten, dan Provinsi Berbasis Identitas(Jakarta: Makna Informasi) 